Tạp chí Khoa học và Công nghệ biển T10 (2010). Số 2. Tr 15 - 29

\title{
SỰ BIẾN ĐỔI HÌNH THÁI ĐỊA HÌNH BÃI VÀ ĐƯờnG BỜ TẠI MộT SỐ KHU VỰC BỜ BIỂN NAM TRUNG Bộ THEO THÒ̀I GIAN (2007 - 2008)
}

\author{
TRẦN VĂN BÌNH, TRỊNH THẾ HIẾU
}

Viện Hải dương học

\begin{abstract}
Tóm tắt: Hình thái địa hình đường bò̀ và bãi biển một số khu vục thuộc vùng bò̀ Nam Trung bộ đang bị tác động mạnh không chỉ bởi các yếu tố tụ nhiên (sóng, gió, dòng chảy ven bò̀, nước dâng do bão, dòng bùn cát...), mà còn do các hoạt động của con người. Tình trạng xói lở - bồi tu bò biến và các của sông diễn ra hàng năm và theo mùa khá rõ rệt. Trong đa số truờng hợp, xói lở bò biển gây ra tai biến nhiều hơn so với bồi tụ. Thêm vào đó, đối với vùng bờ biển Nam Trung bộ, hoạt động bồi tu tại một số cửa sông đã và đang trở thành mối hiểm họa trong quá trình hoạt động phát triển kinh tế - xã hội của các địa phuoong.
\end{abstract}

\section{MỞ ĐẦU}

Bờ biển Nam Trung bộ (Phú Yên - Bình Thuận), có chiều dài khoảng 1170 km, chạy theo các hướng chính là á kinh tuyến (đoạn Phú Yên - Ninh Thuận) và Đông Bắc - Tây Nam (đoạn Bình Thuận đến Vũng Tàu), là phần phía Đông của cấu trúc uốn nếp Mezozoi Đà Lạt, tiếp giáp với thềm lục địa phía Nam Việt Nam. Cấu tạo vùng bờ ở đây là sự đan xen giữa những mũi đá và bờ cát vật liệu bở rời (chiếm khoảng $335 \mathrm{~km}$ ). Đặc điểm chung cho vùng bờ này là phần lớn bờ biển thuộc loại bờ tương đối ổn định, quá trình bồi tụ - xói lở thường chỉ diễn ra ở các cửa sông, khu vực lân cận các cửa sông và các đoạn bờ chịu tác động trực giao của sóng.

Bồi tụ và xói lở là hai mặt đối lập xảy ra một cách tất yếu trong quá trình phát triển địa hình tuân theo quy luật tiến hóa của sự vật. Song vì nhiều nguyên nhân, hoạt động bồi tụ - xói lở gây ra những hậu quả nghiêm trọng đối với cuộc sống của con người. Lúc đó nó trở thành tai biến. Trong đa số trường hợp, xói lở bờ biển gây ra tai biến nhiều hơn so với bồi tụ, tuy nhiên đối với vùng bờ biển Nam Trung bộ, hoạt động bồi tụ tại một số cửa sông cũng đã và đang trở thành mối hiểm họa trong quá trình hoạt động phát triển kinh tế - xã hội của các địa phương trong khu vực.

Để góp phần lý giải quá trình phát triển vùng bờ và đánh giá ảnh hưởng của các hoạt động xói lở - bồi tụ trong phạm vi vùng bờ biển Nam Trung bộ, chúng tôi lựa chọn 3 khu vực có những đặc điểm khác nhau để nghiên cứu, đó là: Bãi biển khu vực cửa đầm Ô Loan 
(Tuy An, Phú yên); Bãi biển Nha Trang (Khánh Hòa); Khu vực bãi biển Đồi Dương (Phan Thiết), cửa La Gi (Hàm Tân), tỉnh Bình Thuận.

\section{TÀI LIỆU VÀ PHƯƠNG PHÁP NGHIÊN CÚU}

\section{Tài liệu}

\section{Tài liệu tổng quan:}

+ Hải đồ tỷ lệ 1:50.000, lưới chiếu UTM, do Hải quân Mỹ thành lập và xuất bản năm 1967 (số liệu năm 1965), gồm các tờ sau: tờ số 93E31 vụng Xuân Đài, tờ 93E28 vịnh Nha Trang và tờ 93E22 Phan Thiết và tờ 93E20 La Gi.

+ Báo cáo tổng kết đề tài KHCN 06.08, 2001, do TSKH. Lê Phước Trình làm chủ nhiệm đề tài và các tài liệu liên quan đã công bố.

+ Báo cáo tổng kết đề tài KHCN.09.05, 2005. "Dự báo hiện tượng xói lở - bồi tụ bờ biển, cửa sông và các biện pháp phòng tránh”. Chủ nhiệm PGS.TS. Phạm Huy Tiến và các tài liệu liên quan.

+ Các ảnh vệ tinh dải ven biển Nam Trung bộ các năm 2007 \& 2008.

\section{Tài liệu khảo sát, phân tích:}

+ Kết quả khảo sát đo đạc chi tiết bãi biển, đường bờ các khu vực: cửa đầm Ô Loan (Phú Yên), bãi Nha Trang (Khánh Hòa), bãi Đồi Dương (Phan Thiết) và khu vực cửa La Gi (Hàm Tân), Bình Thuận, vào thời gian tháng 11/2007 và tháng 8/2008.

+ Kết quả phân tích thành phần cơ học các mẫu trầm tích bãi.

\section{Phương pháp}

- Các tài liệu đã thu thập, được hệ thống, hiệu chỉnh về hệ tọa độ thống nhất, dùng các Hải đồ kết hợp với ảnh vệ tinh để nắn chỉnh hình học, tính toán số liệu đo đạc thực địa. Các kết quả tập hợp được số hoá về cùng một hệ quy chiếu để thành lập các bản vẽ.

- Thành lập các sơ đồ địa hình bãi biển, các mặt cắt ngang địa hình từ số liệu đo đạc chi tiết để thể hiện rõ sự biến động bãi và đường bờ trong thời gian 2 năm.

- Mẫu trầm tích bãi biển được phân tích thành phần độ hạt và thạch học trầm tích.

- So sánh mức độ biến động bãi cũng như đường bờ bằng phương pháp tích hợp dữ liệu đo đạc của hai đợt khảo sát (11/2007 \& 8/2008), trên cùng hệ thống lưới chiếu. 


\section{KẾT QUẢ NGHIÊN CÚU}

\section{Khu vực cửa đầm $\hat{O}$ Loan}

\section{1. Đặc điểm biến đổi bãi biển}

Bãi biển khu vực cửa đầm Ô Loan được hình thành từ doi cát chắn trước cửa đầm Ô Loan, phát triển từ khu vực Xuân Hòa đẩy cửa đầm tiến dần về phía Bắc. Hiện tại đầm Ô Loan thông với biển qua cửa Mái Nhà. Tuy nhiên, vào các thời kỳ mưa lũ lớn thường một cửa đầm mới được mở cắt qua doi cát chắn tại vị trí gần như đối diện với cửa đầm nguyên thủy. Cửa mới mở chỉ tồn tại một thời gian ngắn (thường 3 - 4 tháng) rồi bị lấp lại và sự lưu thông giữa đầm và biển lại chỉ thông qua cửa Mái Nhà. Vào thời gian khảo sát 11/2007, cửa An Hải được mở và lại bị lấp lại sau thời gian 4 tháng tồn tại.

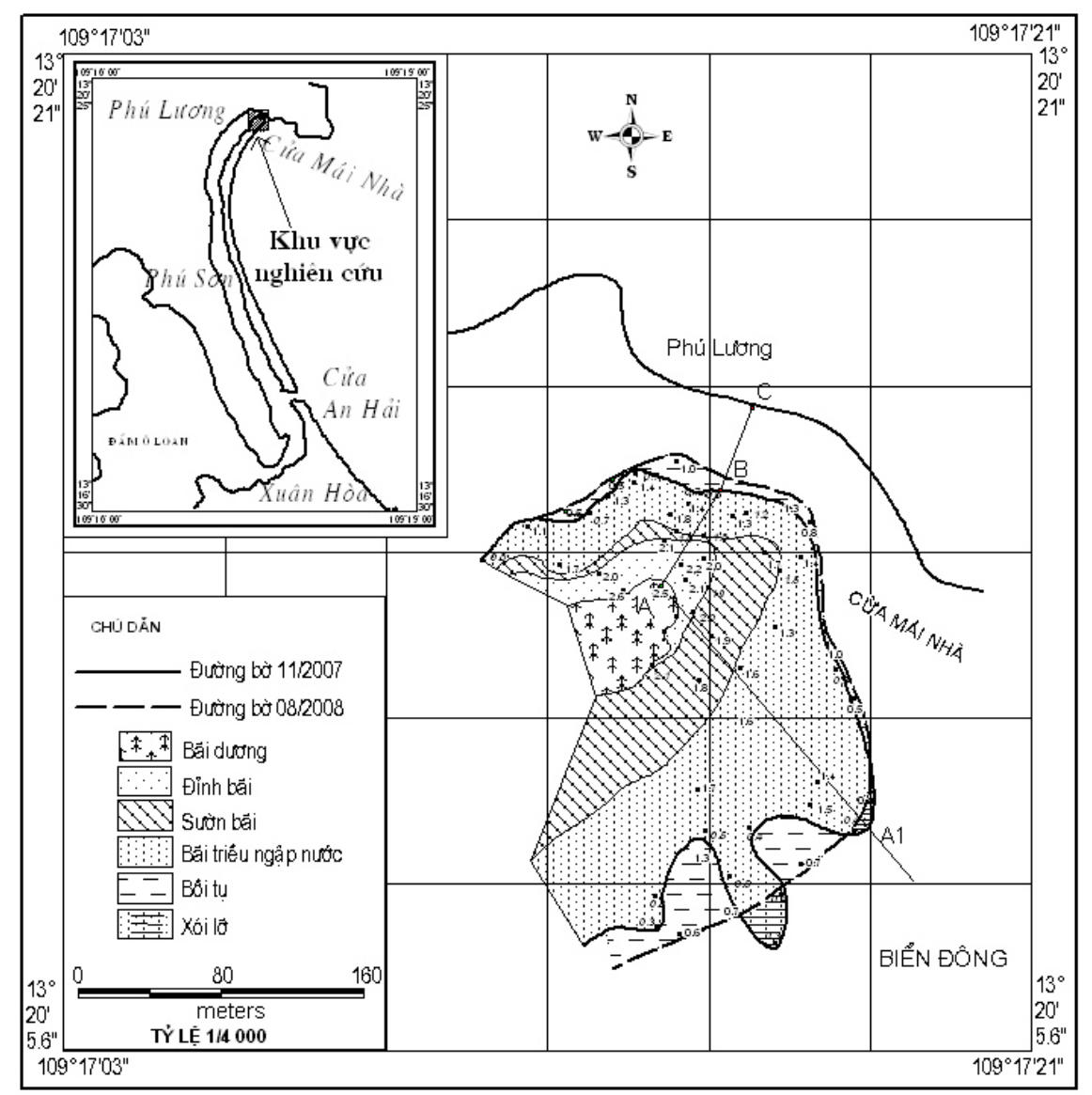

Hình 1: Sơ đồ trắc diện hình thái địa hình bãi biển khu vực cửa Mái Nhà, đầm Ô Loan, tỉnh Phú Yên, năm 2007 - 2008 
Phạm vi khảo sát là sườn phía Đông của doi cát chắn cửa (bãi mặt hướng biển) kéo dài từ phía Nam cửa Mái Nhà đến Xuân Hòa. Bãi có dạng hình cánh cung, kéo dài hơn 7 $\mathrm{km}$. Bãi được cấu tạo bởi trầm tích cát bở rời, chủ yếu là cát hạt nhỏ đến cát trung - lớn chứa sỏi sạn. Địa hình bãi biển thuộc dạng bãi tích tụ - xói lở do tác động của sóng chiếm ưu thế. Sự biến đổi hình thái địa hình bãi theo mùa khá rõ, bãi được bồi tụ vào mùa khô, bị xói lở vào mùa mưa (hình $1 ; 2$ ). Phần phía Bắc bãi (bờ phía Nam cửa Mái Nhà) bãi biển ít bị biến đổi hơn so với ở phía Nam. Bãi biển bị biến động mạnh là khu vực xã An Hải (hình 2-1; 2-2). Tại đây, bãi bị xói lở và cửa $A n$ Hải được mở vào mùa mưa từ tháng 9 đến tháng 12 (ảnh 1), bồi lấp không còn cửa lưu thông vào mùa khô (ảnh 2 , trong thời gian nghiên cứu). Bề mặt bãi nhìn chung rất bằng phẳng, độ cao trung bình của bãi từ $2,5 \mathrm{~m}$ đến $2,7 \mathrm{~m}$, ở độ cao từ $0,5-1 \mathrm{~m}$ độ dốc thay đổi từ $8-10^{0}$.

- Sự biến đổi địa hình bãi theo thời gian 2007- 2008, tại khu vực cửa Mái Nhà được thể hiện trên hình 1-1 và $1-2$ :

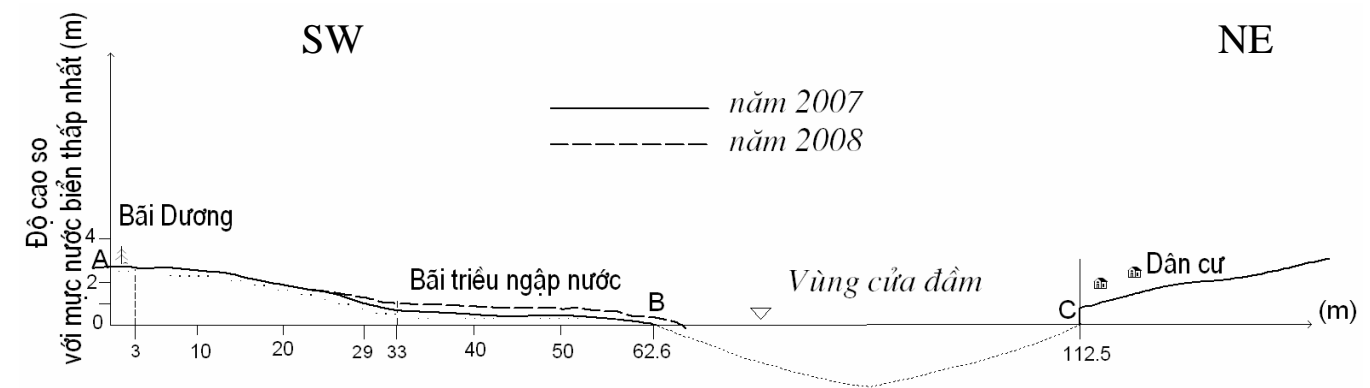

Hình 1-1: Mặt cắt (A-B-C) địa hình bãi biển khu vực cửa Mái Nhà

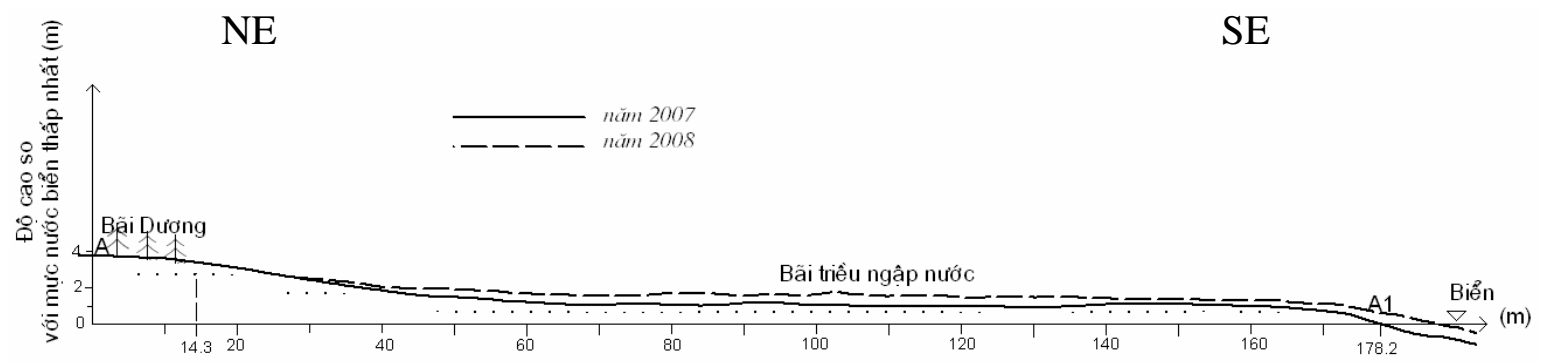

Hình 1-2: Mặt cắt (A-A1) địa hình bãi biển khu vực cửa Mái Nhà 


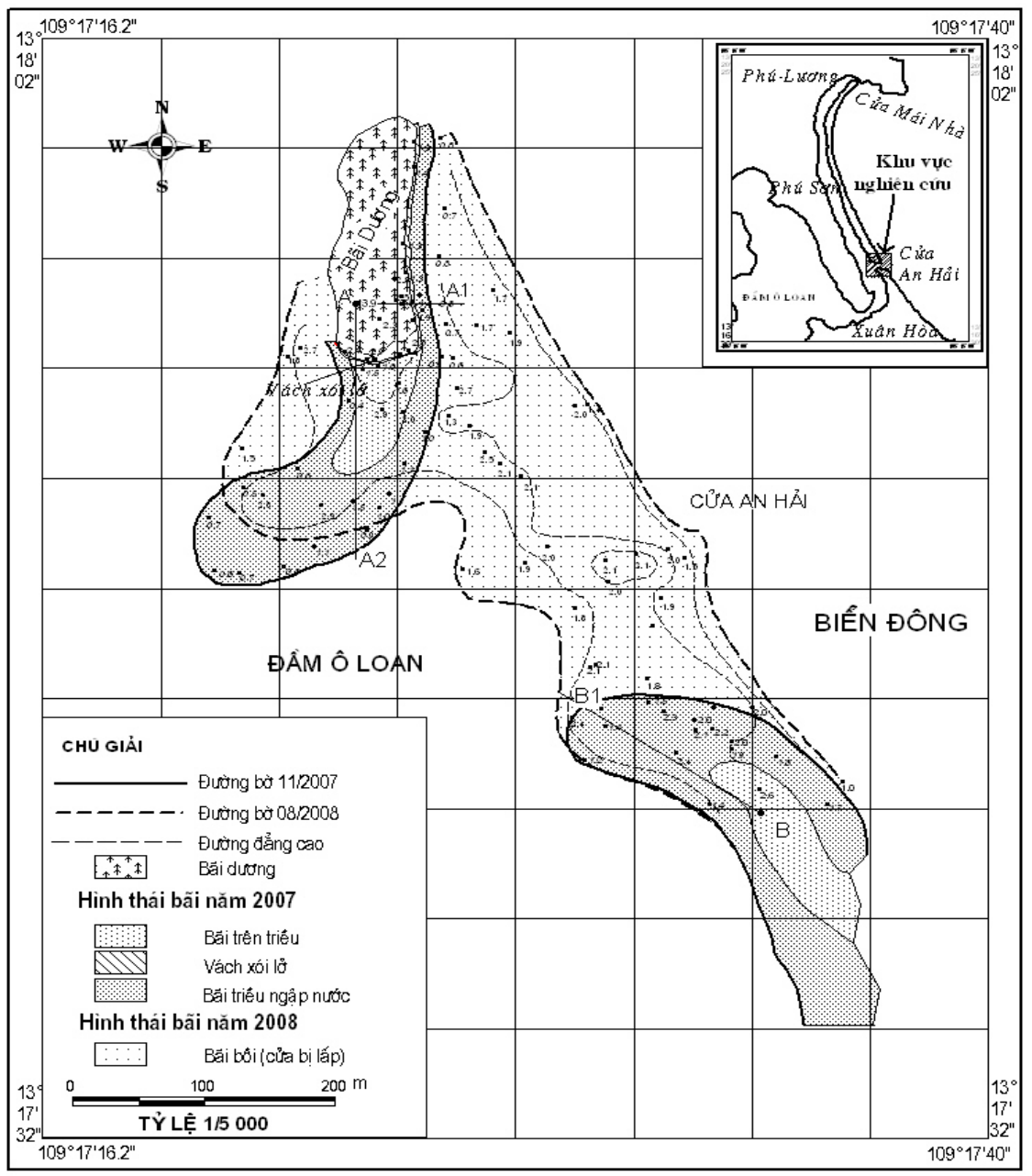

Hình 2: Sơ đồ trắc diện hình thái địa hình bãi biển khu vực cửa An Hải, đầm Ô Loan, tỉnh Phú Yên, năm 2007 - 2008

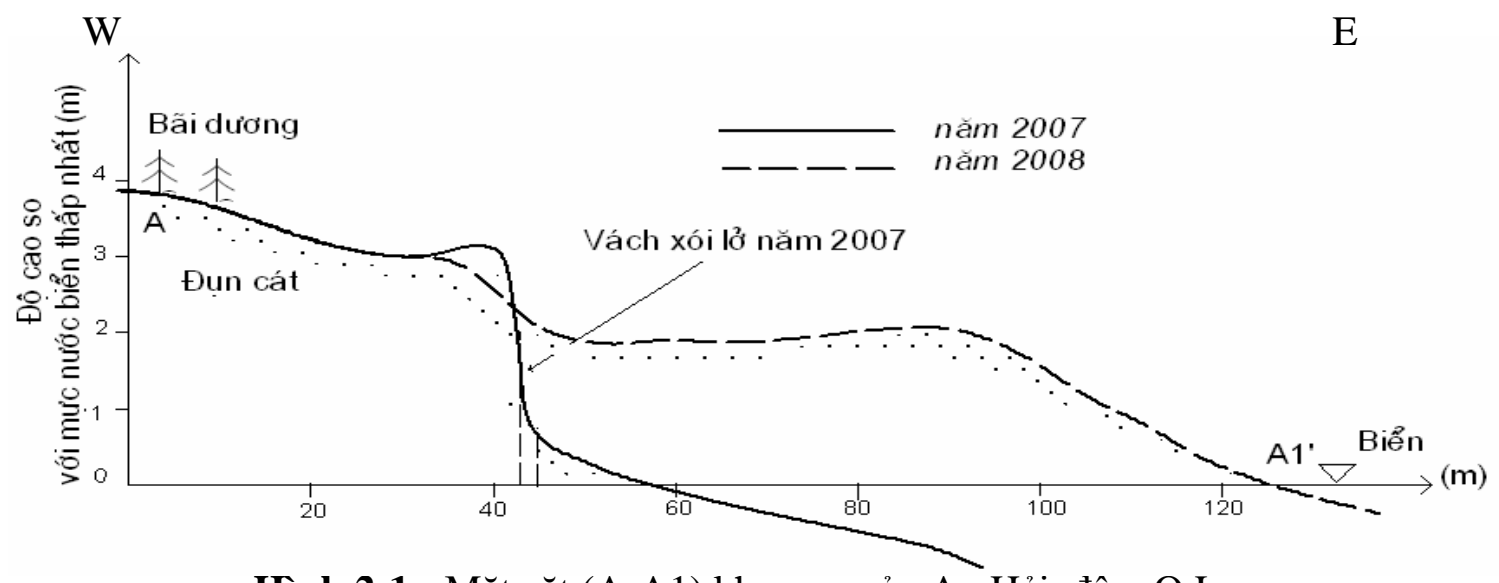

Hình 2-1: Mặt căt (A-A1) khu vực cửa An Hải, đâm O Loan 
- Sự biến đổi địa hình bãi theo thời gian 2007- 2008, tại khu vực cửa An Hải được thể hiện trên hình 2-1 và 2-2:

$\mathrm{N}$

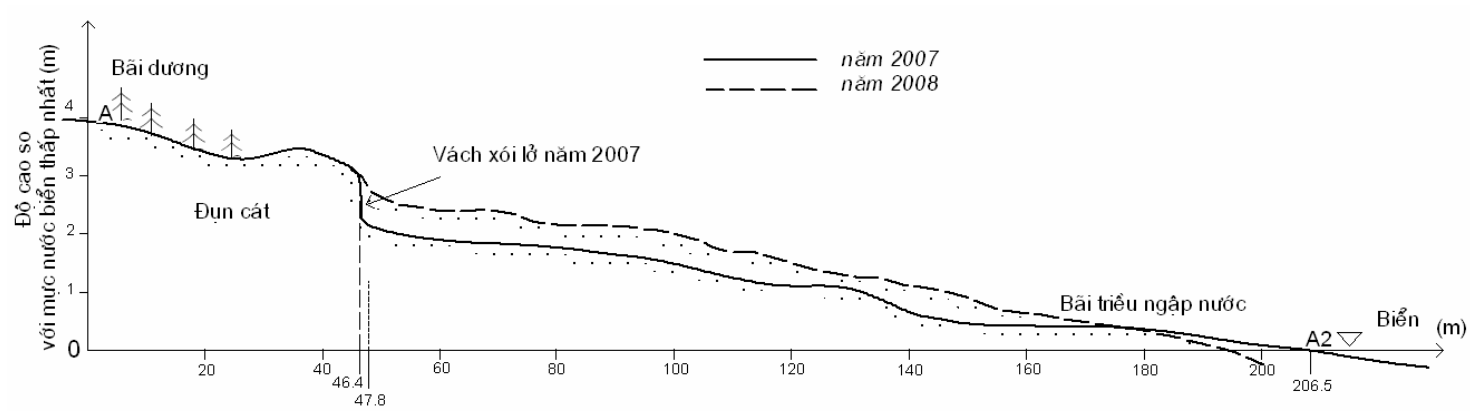

Hình 2-2: Mặt cắt (A-A2) khu vực cửa An Hải, đầm Ô Loan.

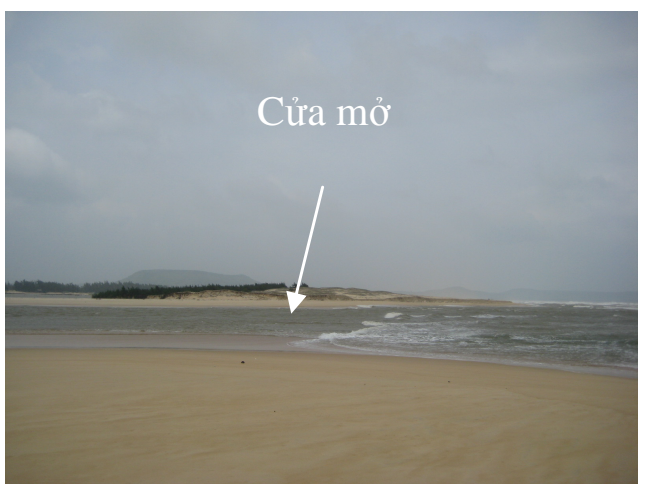

Ảnh 1: Cửa An Hải 11/2007

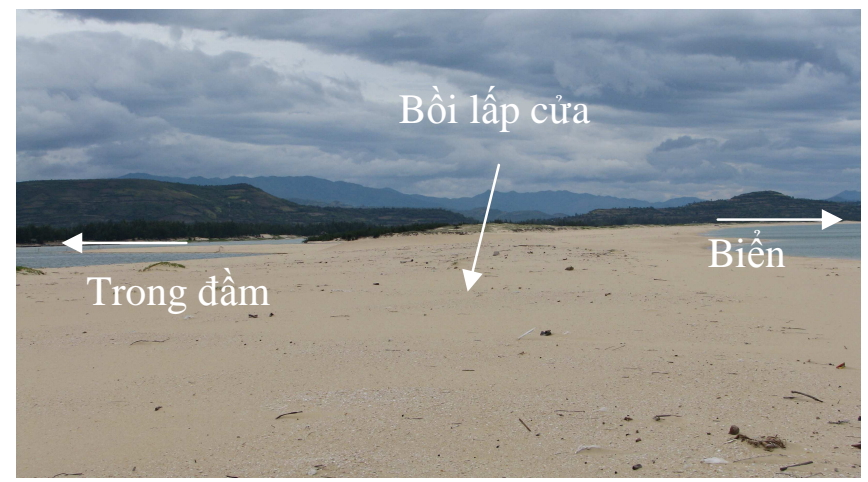

Ảnh 2: Cửa An Hải 8/2008

\section{2. Đặc điểm biến động đường bờ}

Đây là đoạn bờ được cấu tạo bởi các thành phần vật liệu bở rời đồng thời chịu ảnh hưởng nhiều tác động của các quá trình tự nhiên nên rất nhạy cảm với các quá trình sóng, gió và dòng chảy ven bờ. Trong phạm vi đoạn bờ này, hiện tượng xói lở - bồi tụ xảy ra đan xen nhau, trong đó quá trình xói lở chiếm ưu thế, nhiều đoạn xói lở mạnh tạo thành các vách thẳng đứng, cao 0.8 - 1.0 m (hình 2-1).

Ở khu vực phía Nam bãi biến đổi mạnh theo mùa (hình 2): Vào mùa mưa cửa $A n$ Hải được mở, nước đầm Ô Loan chảy thông ra biển chủ yếu theo cửa này, nhưng nó được lấp lại chỉ sau vài tháng hoạt động. Vào mùa khô được bồi lấp gần như hoàn toàn, chỉ để lại dấu vết cửa. 
Về sự biến đổi hình thái đường bờ ở đây có thể lý giải như sau: Vào thời kỳ gió mùa Đông Bắc, bờ chịu tác động trực tiếp của sóng hướng Đông Bắc, vật liệu bờ do sóng phá vỡ được dòng chảy dọc bờ đưa xuống tích tụ ở phía Nam bãi. Điều này được thể hiện khá rõ ràng qua sự phân dị cơ học trầm tích theo hướng Bắc - Nam: ở khu vực phía Bắc, trên bề mặt bãi là cát hạt lớn, trung - lớn, càng về phía Nam độ hạt giảm dần đến cát nhỏ. Vào thời kỳ gió mùa Tây Nam, sóng hướng Đông Nam chiếm ưu thế, xu thế biến đổi bờ theo hướng ngược lại: xói ở phía Nam và bồi ở phía Bắc bãi.

Cơ chế lấp mở cửa biển An Hải cũng như một số cửa biển khác ở miền Trung (cửa Hòa Duân, Tư Hiền ở Thừa Thiên Huế) đã được Trịnh Thế Hiếu (2002 [2]) mô tả khá chi tiết. Chu kỳ thời gian lấp mở các cửa biển này rất khác nhau và phụ thuộc rất nhiều vào các yếu tố ngoại sinh. Theo các tài liệu hiện có (Trần Đức Thạnh và nnk, 1998 [7], Trịnh Thế Hiếu, 2002 [2]), thì chu kỳ lấp - mở cửa Hòa Duân là trên dưới 100 năm; còn đối với cửa Tư Hiền và cửa An Hải chu kỳ lấp - mở không ổn định, thường từ 3 - 4 tháng có thời kỳ 4 - 5 tháng sau khi mở.

\section{Khu vực bãi biển Nha Trang}

\section{1. Đặc điểm biển đổi bãi biển}

Bãi biển Nha Trang có dạng cánh cung ôm lấy phần bờ phía Tây vịnh Nha Trang. Bề rộng bãi thay đổi theo mùa, mùa sóng gió Đông Bắc thường không quá $20 \mathrm{~m}$, mùa sóng gió Đông Nam 25 - 30 m, có khi rộng hơn (Trịnh Thế Hiếu, 1980 [1]).

Trong 2 năm 2007 - 2008, chúng tôi đã tiến hành quan trắc, khảo sát chi tiết khu vực: từ phía Nam cầu Trần Phú đến Quảng Trường $2 / 4$, với chiều dài đoạn bờ trên $2 \mathrm{~km}$ (hình 3). Kết quả quan trắc, khảo sát cho thấy, hình thái địa hình bãi biến đổi rõ rệt từ tháng 11/2007 (mùa gió Đông Bắc) đến tháng 8/2008 (mùa gió Đông Nam), bề rộng bãi thay đổi từ $5-9 \mathrm{~m}$, có nơi lên tới $11 \mathrm{~m}$ (trước UBND tỉnh).

Thành phần vật liệu cấu tạo bãi chủ yếu là cát hạt nhỏ đến hạt trung. Địa hình bãi biển thuộc dạng bãi tích tụ - xói lở do tác động của sóng chiếm ưu thế. Bãi biển thoải đều, ở khu vực phía Bắc bãi có độ dốc dốc hơn phía Nam, độ dốc trung bình của bãi từ 7-8 Hình thái bãi biến đổi theo mùa rất rõ, mùa khô bãi được bồi tụ nâng cao thêm và mỡ rộng, còn vào mùa mưa thi ngược lại bãi bị xói lở - hạ thấp bãi và thu hẹp, hình thành dạng feston rất điển hình (hình 3-1;3-2).

- Sự biến đổi hình thái địa hình bãi theo trắc diện ngang (theo số liệu khảo sát 11/2007 và 8/2008), được thể hiện trên các hình 3-1, 3-2. 


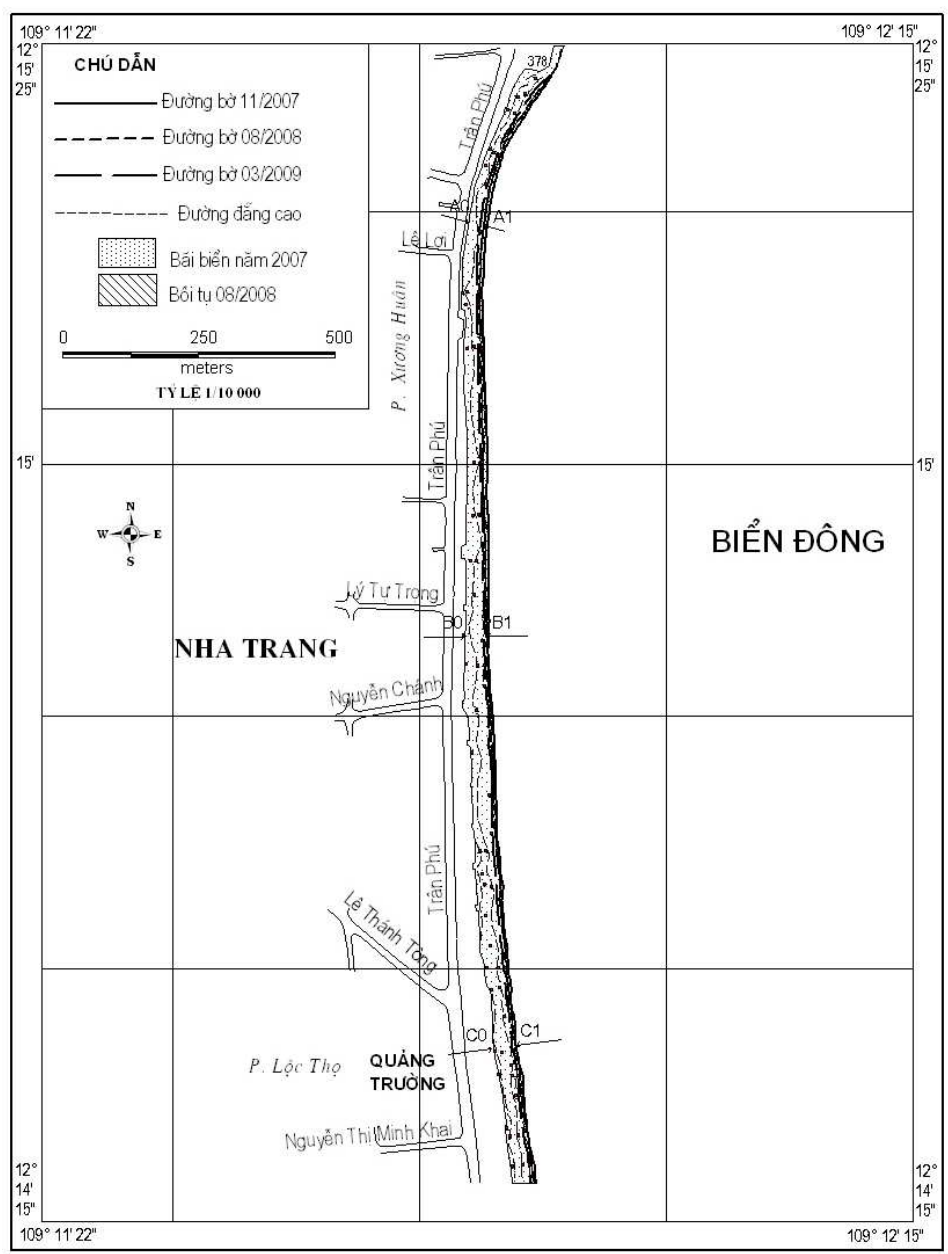

Hình 3: Sơ đồ trắc diện địa hình bãi biển khu vực bãi biển Nha Trang, 2007 - 2008

NW

SE

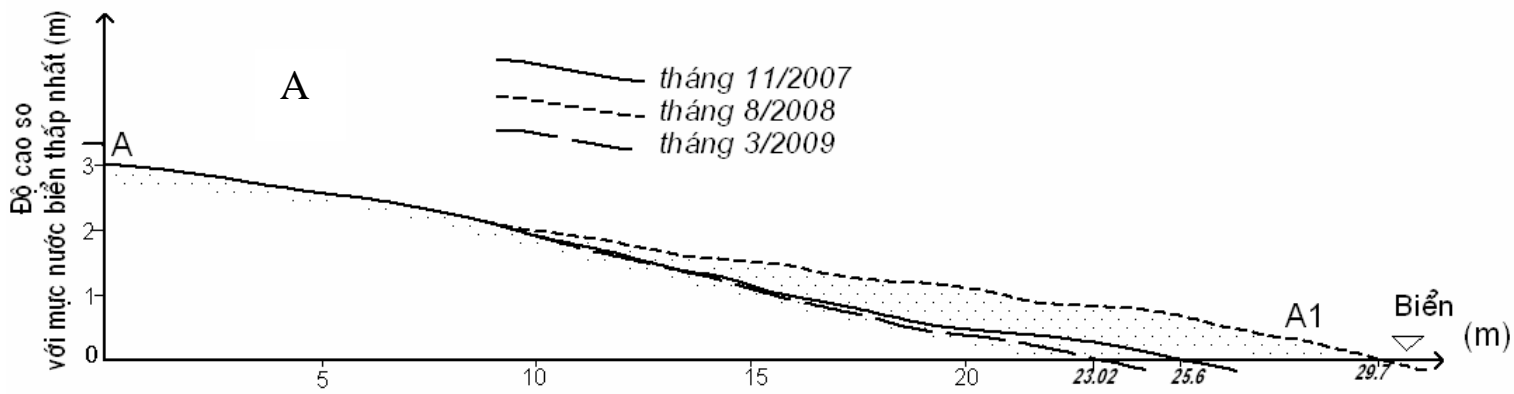

Hình 3-1: Trắc diện ngang bãi Nha Trang theo mặt cắt A0 - A1 


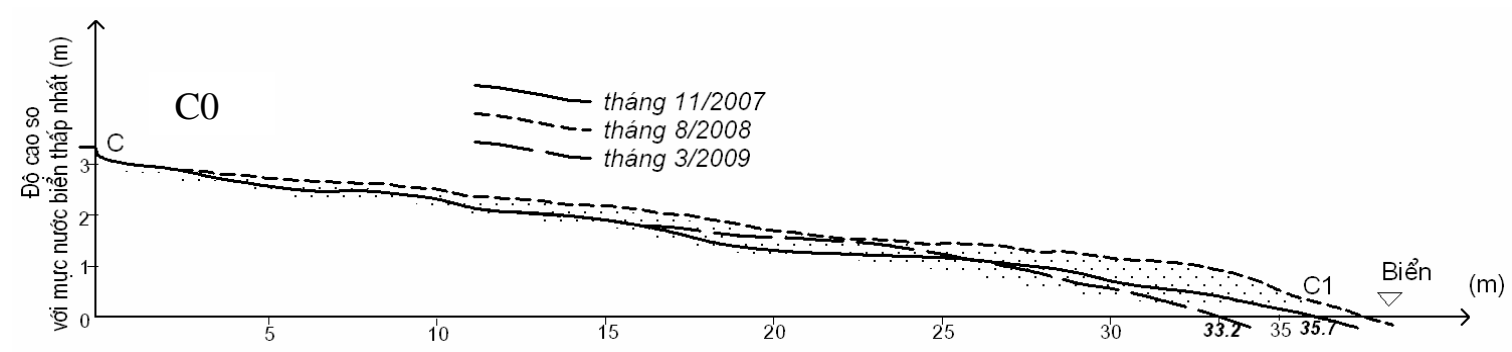

Hình 3-2: Trắc diện ngang bãi Nha Trang theo mặt cắt $\mathrm{C} 0$ - C1

\section{2. Đặc điểm biến động đường bờ}

Bờ biển vùng nghiên cứu nằm trong nhóm bờ biển thành tạo chủ yếu do quá trình sóng, thuộc kiểu bờ biển vũng vịnh mài mòn - bờ xói lở trên các thành tạo cát bở rời. Phía Bắc giáp bờ Nam cửa sông Cái, phía Nam là núi đá Chutt. Về hướng biển, bờ biển Nha Trang được che chắn bởi hệ thống đảo trong vịnh Nha Trang, như: hòn Chà Là, Hòn Đụn, Hòn Ông, Hòn Tre (Hòn Lớn), Hòn Một, Hòn Mun, Hòn Tầm, Hòn Miều. Ngoài ra, còn có bãi cạn Rạn Lớn (Grand Bank) nằm ở phần phía Bắc vịnh Nha Trang. Nằm trong khung cảnh được che chắn như vậy, nên vùng bờ biển Nha Trang được coi là khá ổn định và luôn ở trạng thái cân bằng bền. Tuy nhiên, sự biến đổi theo mùa cũng diễn ra khá rõ nét. Vào thời kỳ gió mùa Đông Bắc, bờ ở phía Bắc thường xảy ra hiện tượng xói lở, vật liệu xói lở được dòng chảy dọc bờ đưa xuống tích tụ ở khu vực phía Nam, vào thời kỳ gió mùa Tây Nam có xu thế ngược lại. Quá trình này được thể rõ qua sự phân dị cơ học trầm tích: mùa gió Đông Bắc cát bãi có kích thước hạt giảm dần từ Bắc xuống phía Nam và mùa gió Tây Nam thì ngược lại.

\section{Khu vực bãi biển Đồi Dương TP. Phan Thiết}

\section{1. Đặc điểm biến đổi bãi biển}

Bãi biển khu vực Đồi Dương TP. Phan Thiết, có hướng Đông Bắc - Tây Nam (hình 4), thành phần vật liệu cấu tạo bãi chủ yếu là cát hạt nhỏ đến trung, bãi có địa hình thấp dần theo hướng Đông Bắc - Tây nam, càng xuống phía nam bề mặt bãi biển bằng phẳng hơn và được cấu tạo bởi vật liệu cát hạt mịn hơn, bãi có độ dốc thoải đều (khi chưa có công trình chắn sóng ven bờ, năm 2007). Đến năm 2008 khi có các công trình chắn sóng ven bờ thì bãi bị biến đổi mạnh, hiện tượng xói lở mạnh vào mùa mưa xảy ra ở đoạn bờ phía Nam bãi biển, nơi không có đê mềm chắn sóng. Nhưng vào mùa khô thì bãi biển nơi đây lại được bồi tụ nhưng không đáng kể (hình 4-1; 4-2). 


\section{2. Đặc điểm biến động đường bờ}

Bờ biển vùng nghiên cứu được cấu tạo chủ yếu bởi các thành phần vật liệu là cát, nơi bị xói mạnh nhất là phía bắc cửa sông Cà Ty, khu vực bãi tắm thuộc bãi Đồi Dương, phường Hưng Long - Phan Thiết với chiều dài hơn $2 \mathrm{~km}$ liên tục bị xói vào thời kỳ mùa mưa lũ hàng năm. Phía Nam sông Cà Ty (phường Hưng Long) bị xói lở liên tục, không những vào mùa mưa mà còn bị xói mạnh vào những đợt triều cường. Do quá trình xói lở xảy ra mạnh mẽ dẫn đến lở đất, sập nhà của cư dân ven biển. Để tránh tai biến dẫn đến thiệt hại, năm 2007 đoạn bãi tắm này đã được bảo vệ bằng các đê mềm chắn sóng. Cửa sông chợ Dinh luôn được dịch chuyển và biến đổi phức tạp qua từng năm.

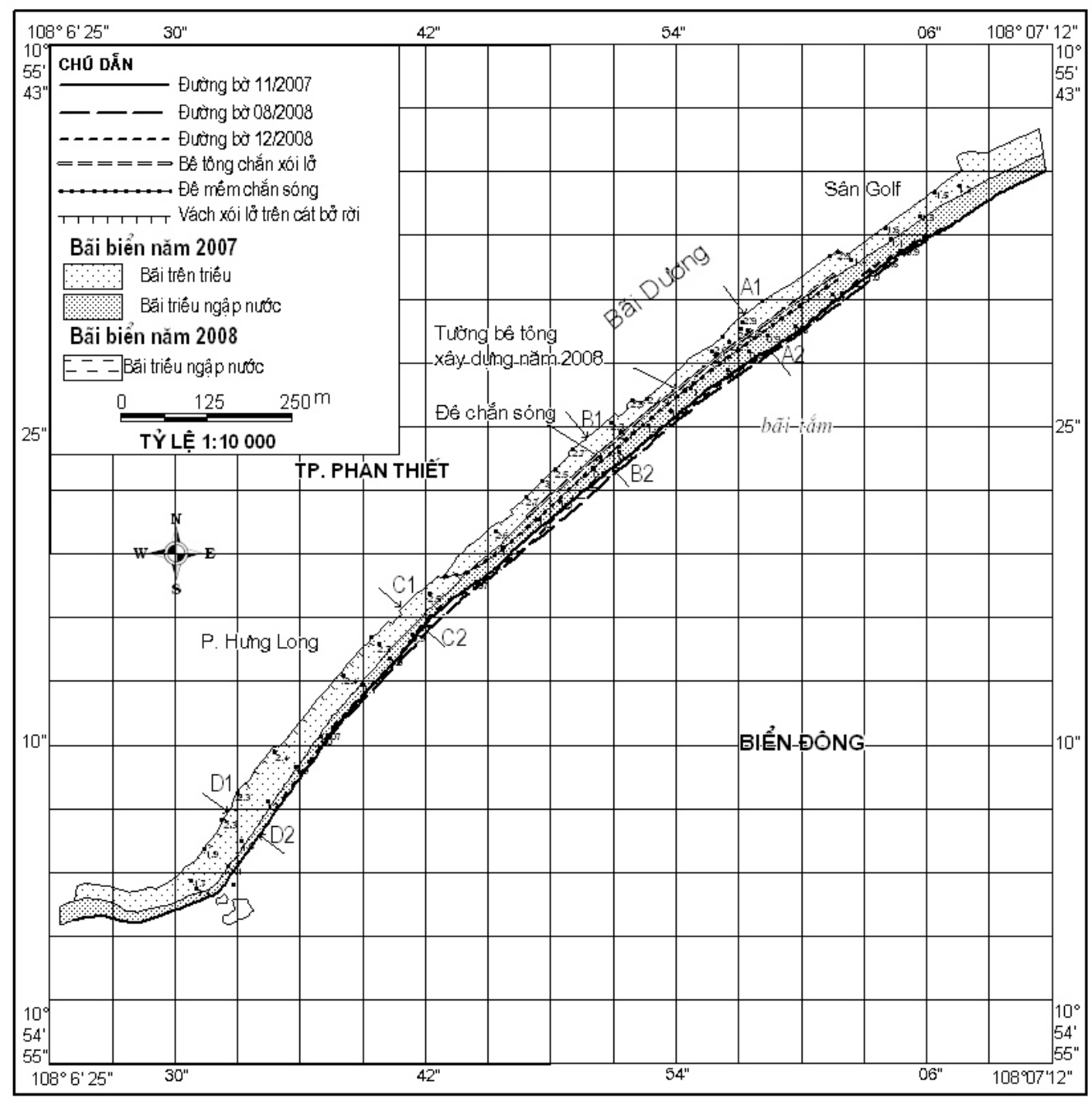

Hình 4: Sơ đồ trắc diện địa hình bãi biển khu vực bãi Đồi Dương, thành phố Phan Thiết, Bình Thuận, 2007 - 2008 
- Sự biến đổi hình thái địa hình bãi Đồi Dương theo thời gian 2007 - 2008, được thể hiện trên các hình 4-1 và 4-2.

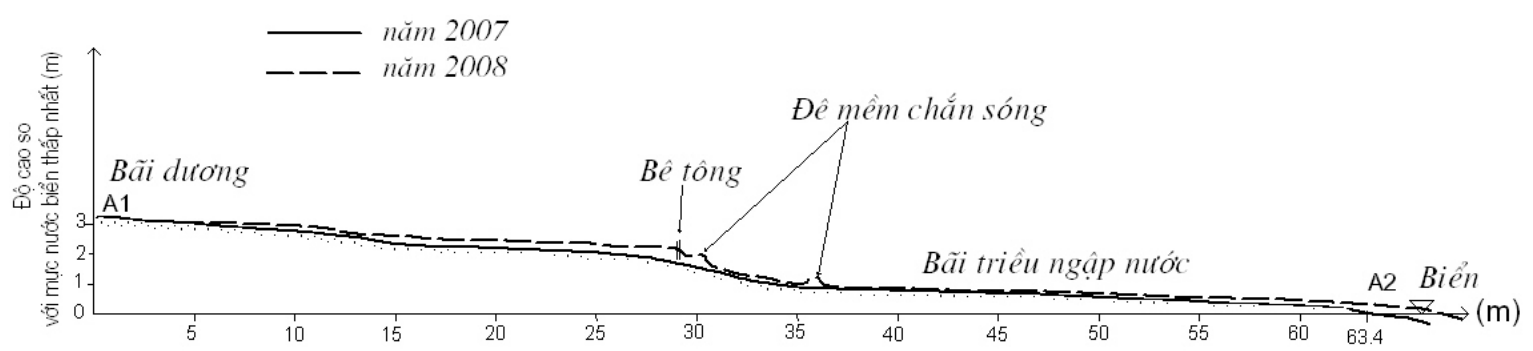

Hình 4-1: Trắc diện ngang bãi Đồi Dương theo mặt cắt $\mathrm{A} 1-\mathrm{A} 2$

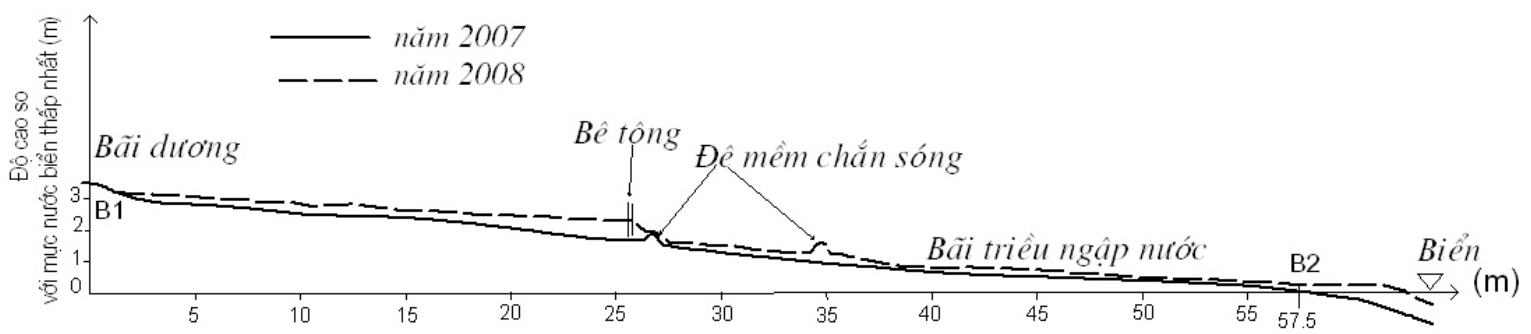

Hình 4-2: Trắc diện ngang bãi Đồi Dương theo mặt cắt B1- B2

\section{Khu vực cửa $L a G i$}

\section{1. Đặc điểm biển đổi bãi biển}

Bãi biển khu vực cửa La Gi, Bình Thuận có hướng Đông Bắc - Tây Nam (hình 4), thành phần vật liệu cấu tạo bãi chủ yếu là cát hạt trung đến lớn, ít sỏi sạn, bãi biển ở phía Bắc cửa La Gi có phần cao hơn ở phía Nam, Địa hình bãi biển thuộc dạng bãi xói lở - tích tụ do tác động của sóng chiếm ưu thế.

Theo số liệu khảo sát thực địa tháng $8 / 2008$, thì bãi biển cả phía Bắc và phía Nam cửa La Gi, có đặc điểm sau: Phần trên bãi, ở độ cao $2,0 \div 2,5 \mathrm{~m}$ là bề mặt khá bằng phẳng, còn phần chân bãi bị ngập triều thì dốc hơn. Nhưng qua mùa mưa, đến tháng 3/2009 thì phần bãi biển ở phía Nam không còn nữa, thay vào đó là những vách xói lở đã ăn sâu vào khu dân cư ven biển, làm sụp đổ hàng trăm nhà dân. Theo kết quả điều tra xã hội học tại khu phố 7 , phường Phước Lộc, thị trấn $\mathrm{La} \mathrm{Gi}$, cho biết: Từ khi có công trình đê kè bê tông ở khu vực cửa La Gi (năm 2003) đến nay, bãi biển ở đây bị xói lở mạnh hơn đặc biệt vào thời kỳ mùa mưa và các đợt triều cường, không còn được bồi tụ vào mùa khô như những 
năm trước đây khi chưa có đê kè này. Điều này chứng tỏ, đã có sự ảnh hưởng của đê kè làm mất cân bằng tự nhiên, dòng bồi tích dọc bờ giảm đi, hiện tượng xói lở xảy ra càng mạnh hơn vào mùa mưa.

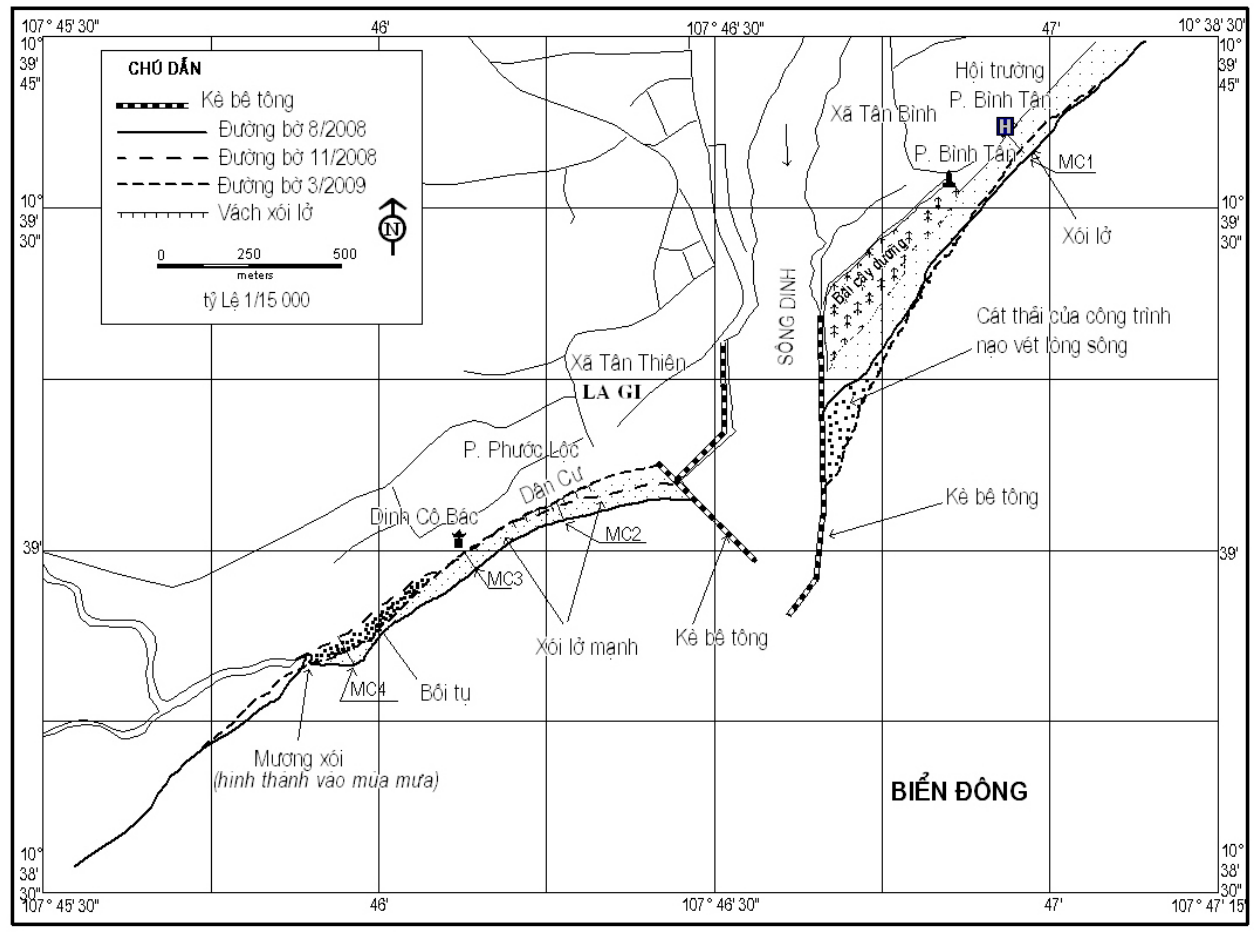

Hình 5: Sơ đồ trắc diện địa hình bãi biển khu vực cửa La Gi, Bình Thuận

- Sự biến đổi hình thái địa hình bãi khu vực phía Nam cửa La Gi theo thời gian, được thể hiện trên hình 5-1.

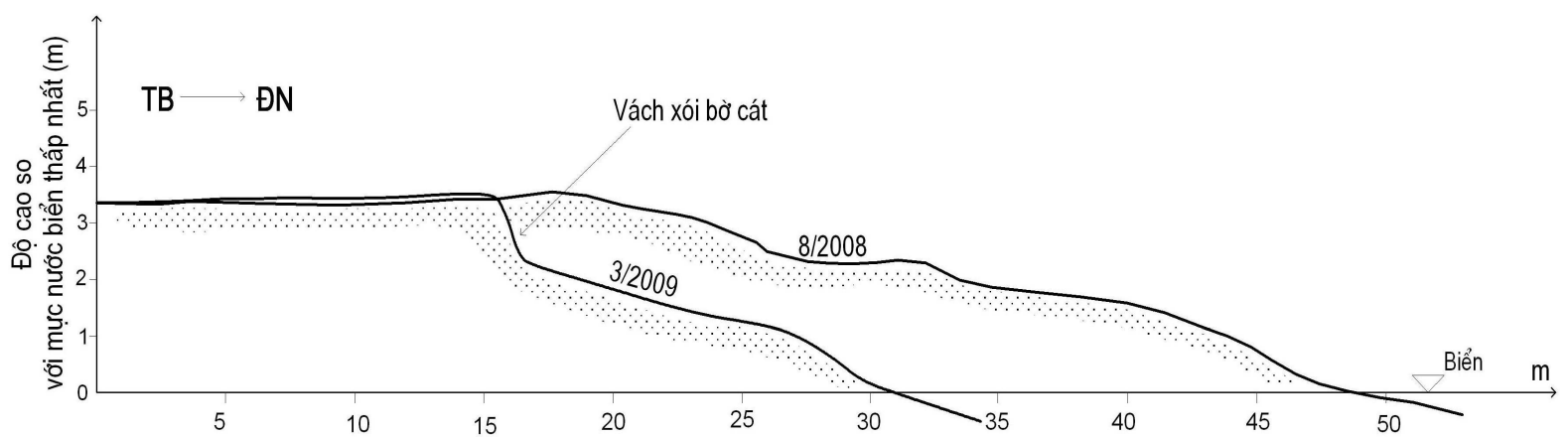

Hình 5-1: Trắc diện ngang địa hình bãi theo mặt cắt MC3 (khu vực Dinh Cô Bác). 


\section{2. Đặc điểm biến động đường bò̀}

Từ kết quả các chuyến khảo sát, đã thành lập sơ đồ bãi và tính toán cường độ bồi tụ xói lở theo mùa trong hai năm tại khu vực này. Kết quả quan trắc, khảo sát đo đạc chi tiết hình thái đường bờ cho thấy, sự biến động mạnh của đường bờ ở đây không chỉ do tác động khá mạnh bởi các yếu tố tự nhiên (do sóng, gió, dòng chảy ven bờ, triều cường kết hợp sóng gió độ cao lớn, dòng bùn cát...), mà còn do các hoạt động khai thác, phá vỡ cân bằng tự nhiên của con người (nạo vét luồng lạch, hút cát trong sông, các công trình đê kề chắn sóng, v.v...). Đây lại đang trở thành nguyên nhân chính làm thay đổi cảnh quan vùng bờ nói chung và gây biến đổi đường bờ nói riêng.

Đối với khu vực phía Bắc cửa La Gi, trong vài năm gần đây tình trạng sạt lở bờ biển xảy ra khá nghiêm trọng, người dân khu phố 9 và 11 , phường Bình Tân, thị trấn La Gi, luôn phải sống trong tâm trạng thấp thỏm, lo âu. Đoạn bờ trước hội trường khu phố 9 (phường Bình Tân) ăn sâu vào đất liền khoảng $1 \mathrm{~m}$ (hình 5 ), đe dọa đến dải rừng phòng hộ hơn 10 năm tuổi. Quan sát vết lộ phần trên bãi có thể nhận thấy, đường bờ khu phía Bắc cửa La Gi ít bị xói lở nhưng bãi biển lại có sự biến đổi mạnh, do chất đổ thải trong quá trình nạo vét lòng sông: phần trên bãi được tôn cao và mở rộng về phía biển. Ngoài ra, còn được đắp thành đê cát chạy dọc bờ biển, từ kè bê tông (phía Bắc) đến hội trường khu phố 9 (phường Bình Tân) khoảng gần $1 \mathrm{~km}$.

Khu vực phía Nam cửa La Gi (khu phố 7 phường Phước Lộc, thị trấn La Gi), vào thời gian 8/2008 bãi biển ở đây còn khá rộng, có nơi rộng tới hàng trăm mét, nhưng qua mùa mưa đến tháng 3/2009 thì phần bãi này đã bị biến mất (hình 5-1). Người dân sống quanh khu vực ven biển phường Phước Lộc, thị trấn La Gi, luôn ở tình trạng lo sợ khi thấy bờ biển ngày càng xói lở nghiêm trọng. Chỉ trong vòng 9 năm, kể từ khi có kè bê tông trước cửa $\mathrm{La} \mathrm{Gi}$, (từ 2003 đến 2009), quá trình xói lở bờ biển làm bãi cát ven biển rộng hàng vài trăm mét, dài gần $1 \mathrm{~km}$ nay đã bị xóa sổ. Không những thế, đường bờ biển bị đẩy lùi sâu vào bên trong. Từ tháng 8/2008 đến tháng 03/2009 có đoạn lấn sâu vào đất liền cả $100 \mathrm{~m}$ với hàng triệu $\mathrm{m}^{3}$ cát bị mất đi. Đến nay đã có hàng trăm nhà dân bị sóng biển đánh sụp đổ.

\section{KẾT LUẬN}

Sự biến đổi hình thái địa hình bãi và đường bờ tại các khu vực nghiên cứu theo thời gian, do tác động không chỉ của các yếu tố tự nhiên (sóng, gió, dòng chảy dọc bờ,...), mà còn do chính các hoạt động của con người (xây dựng công trình đê kè, nạo vét luồng lạch cửa sông, khai thác cát dưới lòng sông,... ). 
Vùng bờ biển Phú Yên - Bình Thuận có nhiều vị trí có vị thế đặc biệt thuận lợi cho việc phát triển kinh tế - xã hội mang tầm khu vực, Quốc gia và Quốc tế; nhiều đoạn bờ biển tuyệt đẹp với các bãi tắm được đánh giá ở tầm khu vực, song cũng nhiều đoạn bờ biển đang đứng trước nguy cơ bị biến mất do biển lấn.

Tai biến bồi tụ - xói lở bờ biển cửa sông đã trở thành phổ biến ở dải ven biển Việt Nam nói chung và vùng ven bờ Nam Trung bộ nói riêng. Các tai biến này có xu hướng ngày càng gia tăng cả về quy mô và cường độ, do nhiều nguyên nhân (từ hiệu ứng của biến đổi khí hậu), trong đó tác động do hoạt động con người lại đang trở thành một trong những tác nhân chính. Vì vậy, cần thiết phải nghiên cứu để có các giải pháp kỹ thuật phù hợp chống xâm thực, bảo vệ bờ biển, bãi tắm cũng như cảnh quan tự nhiên ở vùng bờ.

\section{TÀI LIỆU THAM KHẢO}

1. Trịnh Thế Hiếu, 1980. Đặc điểm trầm tích các bãi cát hiện đại ven bờ biển Phú Khánh. Tuyển tập nghiên cứu biển, tập II.

2. Trịnh Thế Hiếu, 2002. Status and tendency change of river mouth and lagoon in the Mid-Central and Southern Central Vietnam. Col. Mar. Res. Works. Vol. XII, 111118.

3. Trịnh Thế Hiếu, Lê Phước Trình, Tô Quang Thịnh, 2005. Hiện trạng và dự báo sự biến động bờ biển và các cửa sông ven biển Việt Nam. Tuyển tập báo cáo Hội nghị 60 năm Địa chất Việt Nam, 359-366.

4. Vũ Văn Phái, (1996). Địa mạo khu bờ biển hiện đại Trung bộ Việt Nam - Luận án PTS Địa mạo và cổ địa lý - ĐHQG Hà Nội.

5. Phạm Quang Sơn, 2002. Đặc điểm biến động địa hình các cửa sông miền Trung Việt Nam và vấn đề tiêu thoát nước lũ. Tạp chí khoa học về Trái Đất số 1, 24.

6. Phạm Huy Tiến và cs., 2005. Dự báo hiện tượng xói lở - bồi tụ bờ biển, cửa sông và các biện pháp phòng tránh. Báo cáo tổng kết đề tài cấp Nhà nước. Lưu trữ Bộ KH \& CN, Hà Nội.

7. Trần Đức Thạnh, Trần Đình Lân, Nguyễn Hữu Cử, Nguyễn Chu Hồi, Trần Quang Tuấn, Phạm Văn Huấn, Phạm Văn Vy, 1998. Nguyên nhân bồi lấp cửa Tư Hiền ở hệ đầm phá Tam Giang - Cầu Hai.Tài nguyên và môi trường biển. T.V. NXB. Khoa học và Kỹ thuật. Hà Nội. 
8. Lê Phước Trình, Bùi Hồng Long, Trịnh Thế Hiếu, 2000. Nghiên cứu quy luật và dự đoán xu thế bồi tụ - xói lở vùng ven biển và cửa sông Việt Nam. Báo cáo tổng kết Đề tài KHCN - 06.08. Lưu trữ Bộ KH \& CN, Hà Nội.

9. O.K. Leontyev, L.G. Nikiforv, G.A. Xafianov. Địa mạo bờ biển. Biên dịch: Bộ môn Địa Mạo - Khoa Địa Lý - Trường ĐHKHTN.

\title{
THE TEMPORAL CHANGES OF TOPOGRAPHIC MORPHOLOGY OF BEACHES AND COASTLINES AT SOME AREAS OF SOUTH CENTRAL VIETNAM (2007 - 2008)
}

\section{TRAN VAN BINH, TRINH THE HIEU}

\begin{abstract}
Summary: Topographic morphology of beaches and coastlines in some areas of South Central Vietnam have been affecting strongly not only by natural factors (such as waves, wind, near-shore currents, storm water surges, mud - sand flow...), but also by human activities. The obvious erosion - deposition processes of beaches and estuaries are happening annually and seasonally. In most of cases, coastal erosion caused more disasters than the multiple depositions. In addition, the depositions at some estuaries have been becoming threats for local socio-economic activities.
\end{abstract}

Ngày nhận bài: 21- 10 - 2009

Ngưòi nhận xét: TS. Phùng Văn Phách 